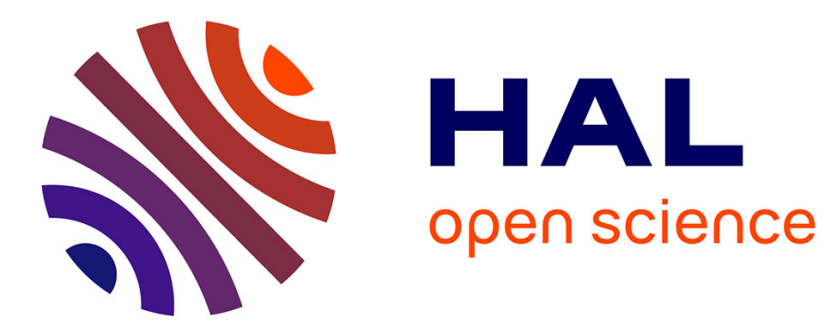

\title{
Multielectron Excitations Above the Xenon L Edges
}

\author{
T. Tochio, Y. Ito, T. Mukoyama, M. Takahashi, S. Emura
}

\section{To cite this version:}

T. Tochio, Y. Ito, T. Mukoyama, M. Takahashi, S. Emura. Multielectron Excitations Above the Xenon L Edges. Journal de Physique IV Proceedings, 1997, 7 (C2), pp.C2-1263-C2-1264. 10.1051/jp4:19972224. jpa-00255298

\section{HAL Id: jpa-00255298 https://hal.science/jpa-00255298}

Submitted on 1 Jan 1997

HAL is a multi-disciplinary open access archive for the deposit and dissemination of scientific research documents, whether they are published or not. The documents may come from teaching and research institutions in France or abroad, or from public or private research centers.
L'archive ouverte pluridisciplinaire HAL, est destinée au dépôt et à la diffusion de documents scientifiques de niveau recherche, publiés ou non, émanant des établissements d'enseignement et de recherche français ou étrangers, des laboratoires publics ou privés. 


\title{
Multielectron Excitations Above the Xenon L Edges
}

\author{
T. Tochio, Y. Ito, T. Mukoyama, M. Takahashi* and S. Emura* \\ Institute for Chemical Research, Kyoto University, Uji, Kyoto 611, Japan \\ * The I.S.I.R., Osaka University, Mihogaoka 8-1, Ibaraki, Osaka 567, Japan
}

\begin{abstract}
The X-ray absorption cross section above the $\mathrm{L}$ edges in Xenon gas has been measured using synchrotron radiation. Multielectron excitation effects are investigated over a few hundred $\mathrm{eV}$ region from the Xe- $\mathrm{L}_{\mathrm{I}}$, $\mathrm{L}_{\mathrm{II}}$, and $\mathrm{L}_{\mathrm{III}}$ edges and the contributions from the effects of shakeup and shakeoff to the photoabsorption spectrum are elucidated. Several features for the multielectron excitations were detected and analyzed by the theoretical energy of the shake up process. Previous observations of the [2(s,p)5(s,p)] and [2(s,p)4d] transitions have been confirmed. [2(s,p)4p], [2s $4 s]$, and [2s3d] transitions are clearly identified in the present study and the difference between the $\mathrm{L}_{\mathrm{I}}$ and $\mathrm{L}_{\mathrm{II}}, \mathrm{L}_{\mathrm{III}}$ edges for the change in slope of the absorption curve in passing through the three identified two-electron excitations is investigated.
\end{abstract}

\section{INTRODUCTION}

For the gaseous state of $\mathrm{Xe}$, the measurements of $\mathrm{x}$-ray-absorption spectra in Xe $\mathrm{L}$ edges have been performed in the energy region of XAFS in order to clearfy the shake effects to the single-electron excitation [1,2]. However, the observation for the change in slope of the absorption curve above $L$ edges is quite different from each other in refs. 1 and 2 . It is a very important problem to investigate the details of atomic structure and excitation dynamics of Xe to elucidate the contribution of the multielectron excitation to XAFS oscilations.

Recently, MacDonald et al. [3] reported the interesting results on resonance Raman scattering which are shown for Xe $\mathrm{L} \alpha_{1,2}(\mathrm{~L} 3 \mathrm{M} 4,5)$ and $\mathrm{Xe} L \beta_{2,15}$ (L3N4,5) $\mathrm{x}$-ray emission when the excitation energy is scanned across the $\mathrm{L}_{\mathrm{III}}$ edge. Moreover, Chaboy and Tyson [4] suggested the contribution of the resonance Raman scattering to XAFS oscillation, especially, in the LN4,5 edges of elements found in the six row of the periodic table.

In this proceedings, we present the study of the multiple photoabsorption cross sections measured in an $x$-ray absorption spectrum of Xe gas at room temperature. Multiple excitation effects are investigated over a 2-keV region from the Xe- $\mathrm{L}_{\mathrm{III}}$ edge, and the contributions from the effects of shakeup and shakeoff to the photoabsorption spectrum are investigated and the difference in the change in slope of the absorption curve is investigated.

\section{EXPERIMENTAL}

The X-ray absorption spectra for Xe were measured using the beam line BL-7C of the Photon Factory Ring in National Laboratory for High Energy Physics, KEK, Tsukuba, with $2.5 \mathrm{GeV}$ positrons at a circular current of $260-360 \mathrm{~mA}$ for $24 \mathrm{~h}$. The harmonic content in the x-ray beam at the low energy was so great that the residual harmonic content contributed sufficient nonlinearities to cause significant noise. Therefore, it was necessary to minimize the harmonic content in the incoming beam. The radiation was reflected with two mirrors made of quartz to reduce the harmonic content less than $10^{-5}$ in the intensity ratio. The calculated energy resolution ( combined intrinsic crystal resolution and vertical angular divergence of the beam) was less than $1 \mathrm{eV}$ at the $\mathrm{Xe} \mathrm{L}_{\mathrm{III}}$ edge. The xenon gas sample of the research grade purity was contained at pressure of atom (or $\mathrm{Kg} / \mathrm{cm}^{2}$ ) in a sealed cell of $50-\mathrm{mm}$ length having $25 \mathrm{~mm}$ Kapton windows. Data were collected at room temperature. To reject the electric noise and the mechanical noise caused by vibration of the sample and the optical systems, an electric low pass filter is applied. The frequency passed to a counter is lower than $0.2 \mathrm{~Hz}$, equivalent to $5 \mathrm{sec}$ of the time constant, leading to a sufficient low noise to extract the very weak multielectron excitation signals from the row observed spectra. 


\section{RESULTS \& DISCUSSION}

The [2(s,p)5p], [2(s,p)5s], and [2(s,p)4d] transitions previously observed by other workers $(1,2)$ were confirmed in this work. The measured energies of these edges agree well with those reported by Zhang et al. [1] (Table 1). The assignments and energies of the various edges are summarized in Table 1. Theoretical values of the energies for multiple vacancies were calculated as the difference in the total electronic energies between the ground state and the state with multiple vacancy using the Dirac-Fock (DF) method [5]. Calculations of the shakeup and shake-off probabilities were performed by the Hartree-Fock-Slater method [6]. First, the shake-up-plus-shakeoff probability was obtained in a manner similar to the method of Carlson and Nestor [7] and the the shakeup probabilities to various Rydberg states were calculated. The shakeoff probability was evaluated by subtracting the sum of shakeup probabilities from the shakeup-plus-shakeoff probability. It is considerable that the sharp threshold onsets observed here are ascribed to the shakeup excitations from the probability of the shake processes suggested by Schaphorst et al.[8], Armen et al.[9], and Ito et al. [10]. In addition, the transition edges of [2s3d] multielectron excitation was first observed by differentiating the absorption cross section above $\mathrm{Xe}_{\mathrm{I}}$. edge with the energy (Fig. 1). The onset of [2s3d] double electron transition is good consistent with its theoretical values. It is confirmed in this study that there is undoubtedly the difference between the $\mathrm{L}_{\mathrm{I}}$ and $\mathrm{L}_{\mathrm{II}}, \mathrm{L}_{\mathrm{III}}$ edges in the change in slope of the absorption curve as previously mentioned by Zhang et al.[1]. Although it is conceivable for resonance Raman scattering to contribute toward this, for example, a little difference in $\mathrm{L}_{\mathrm{II}}$ and $\mathrm{L}_{\text {III }}$ edges in slope of the absorption curve, the difference may be based on the substantial atomic structure including the excitation mechanism.

This work has been performed under the approval of the Photon Factory Program Advisory Committee (Proposal No. 94G-238). We appreciate Mr.Kakuichi for his helping to making the gas cell.

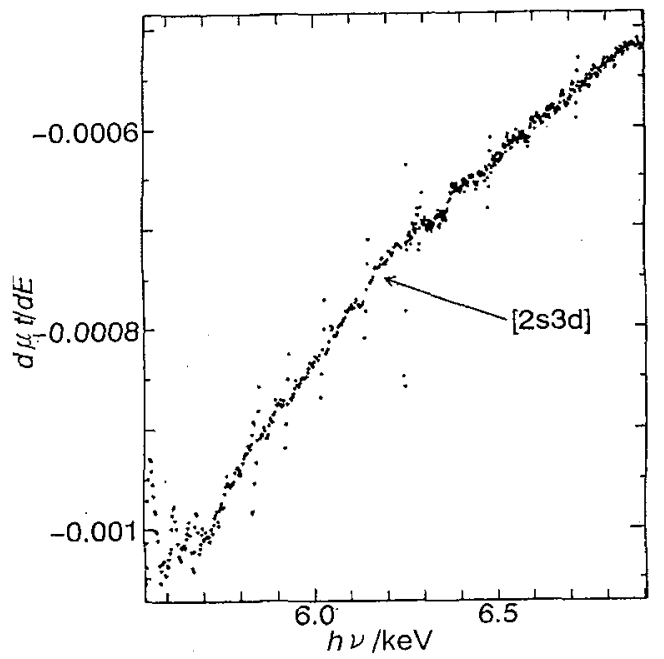

Table I

Positions of double excitations in Xe measured from threshold energies (eV)

\begin{tabular}{|c|c|c|c|c|c|c|}
\hline & $6 p_{1 / 2,3 / 2}$ & $6 s$ & $5 d_{3 / 2,5 / 2}$ & $6 \mathrm{p}_{1 / 2,3 / 2}$ & $6 s$ & $5 d_{3 / 2,5 / 2}$ \\
\hline$L_{1}$ & [2s5p] & [2s5s] & {$[2 s 4 d]$} & [2s4p] & [2s4s] & [2s3d] \\
\hline off & 22,24 & 39 & 89,91 & 181,194 & 248 & 740,753 \\
\hline up & 15,17 & 30 & 80,82 & 174,187 & 239 & 731,745 \\
\hline()$\left.^{*}\right)$ & 13 & 25 & 76 & 166 & $213(233)$ & 718 \\
\hline ref.I & 12 & 23 & 78 & & & \\
\hline & & & & & & \\
\hline$L_{11}$ & 2p5p] & {$[2 \mathrm{p} 5 \mathrm{~s}]$} & {$[2 p 4 d]$} & [2p4p] & [2p4s] & [2p3d] \\
\hline off & 22,24 & 39 & 89,90 & 181,194 & 249 & 741,752 \\
\hline up & 15,17 & 30 & 80,82 & 175,187 & 240 & 733,743 \\
\hline$\left(^{*}\right)$ & 11 & 21 & 71 & 167 & $\therefore$ & \\
\hline ref.I & 12 & 23 & 78 & & & \\
\hline & & & & & & \\
\hline$L_{\text {ill }}$ & [2p5p] & [2p5s] & [2p4d] & [2p4p] & $\frac{[2 p 4 s]}{249}$ & $\frac{[2 \mathrm{p} 3 \mathrm{~d}]}{739755}$ \\
\hline off & 22,24 & 39 & 89,91 & 181,195 & 249 & 739,755 \\
\hline up & 15,17 & 30 & 80,82 & 175,187 & 240 & 733.743 \\
\hline (*) & 11 & 26 & 73 & 173 & - & \\
\hline ref.l & 12 & 23 & 78 & & & \\
\hline
\end{tabular}

(") present study

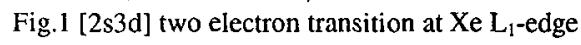

\section{References}

[1]K.Zhang,E.A.Stern,J.J.Rehr, and F.Ellis, Phys.Rev.B44,2030 (1991).

[2]I.Arcon,A.Kodre,M.Stuhec, and D.G-Cindro, Phys.Rev.A51, 147 (1995).

[3]M.A.MacDonald,S.H.Southworth,J.C.Levin,A.Henins,R.D.Deslattes,T.LeBrun,Y.Azuma,P.L.Cowan, and B.A.Karlin, Phys.Rev.A51, 3598 (1995).

[4]J.Chaboy and T.A.Tyson, Phys.Rev.B49, 5869 (1994).

[5]J.P.Desclaux, Comput.Phys.Commun.9,31 (1975).

[6]T.Mukoyama and K.Taniguchi, Bull.Inst.Chem.Res.Kyoro Univ.70,1 (1992).

[7]T.A.Carlson and C.W.Nestor,Jr.,Phys.Rev.A8,2887 (1973).

[8]S.J.Schaphorst, A.F.Kodre, J.Ruscheiski, B.Crasemann,T.Aberg, J.Tulkki,M.H.chen, Y.Azuma, and G.S.Brown, Phys.Rev.A47,1953 (1993).

[9]G.B.Armen,T.Aberg,K.Karim,J.Levin,B.Crasemann,G.Brown,M.Chen, and G.Ice, Phys.Rev.Lett.54,182 (1985)

[10]Y.Ito,H.Nakamatsu,T.Mukoyama,K.Omote,S.Yoshikado,M.Takahashi, and S.Emura, Phys.Rev.A46,6083 (1992). 